\title{
Histone-Lysine N-Methyltransferase EZH2
}

National Cancer Institute

\section{Source}

National Cancer Institute. Histone-Lysine N-Methyltransferase EZH2. NCI Thesaurus. Code C30175.

Histone-lysine $\mathrm{N}$-methyltransferase EZH2 (746 aa, $85 \mathrm{kDa}$ ) is encoded by the human EZH2 gene. This protein is involved in the regulation of chromatin modification. 